DOI 10.37882/2500-3682.2020.12.11

\title{
ПРОБЛЕМА ДУХОВНЫХ ОСНОВ ГОСУДАРСТВЕННОСТИ В РУССКОЙ РЕЛИГИОЗНОЙ ФИЛОСОФИИ КОНЦА 19 - НАЧАЛА 20 ВЕКА
}

\section{THE PROBLEM OF THE SPIRITUAL FOUNDATIONS OF STATEHOOD IN RUSSIAN RELIGIOUS PHILOSOPHY OF THE LATE 19 - EARLY 20 CENTURY \\ E. Gromov}

Summary: The purpose of the study is to identify the features of the disclosure of the topic of the spiritual foundations of statehood in Russian religious philosophy. The article clarifies questions about the reflection of statehood in Russian philosophy, reveals the influence of various religious traditions on their understanding of the origin, essence and historical mission of the state. The scientific novelty of the research lies in the comprehensive analysis of the coverage of the problem of statehood in Russian religious philosophy. As a result, it is substantiated that the main issue around which the solution of this problem was built in Russian philosophy of the indicated period was the question of the moral meaning of the state.

Keywords: Russian religious philosophy, statehood, total unity, moral foundations of the state, etatism, Tolstoyism, eschatology.

\section{Введение}

A ктуальность темы исследования обусловлена с одной стороны - ростом интереса к русской религиозной философии в течение последних лет как со стороны научного сообщества, так и со стороны общества в целом; с другой - нерешённостью проблемы государственности и её духовно-нравственных истоков в современной социально-философской мысли. Богатое наследие русской религиозной философии конца девятнадцатого - первой половины двадцатого века, включающее целый ряд подходов к исследованию государства как феномена культуры активно осваивается как исследователями различных направлений, так и политическими силами и масс-медиа, но по большей части бессистемно и без должного теоретического осмысления. Ряд положений таких философов, как И.А. Ильин, Л.А. Тихомиров, Н.А. Бердяев используются, часто будучи вырванными из контекста, в качестве политических лозунгов. Всё это обусловливает дискуссионность данной проблемы.

Данное исследование преследовало цель выявить особенности раскрытия темы духовных основ государственности в русской религиозной философии конца
Громов Егор Валерьевич

К.ф.н., дочент, Казанский (Приволжский) федеральный университет, Елабужский институт

gromove@mail.ru

Аннотация: Цель исследования - выявить особенности раскрытия темы духовных основ государственности в русской религиозной философии. В статье проясняются вопросы о рефлексии государственности в русской философии, выявляется влияние различных религиозных традиций на осмысление ими происхождения, сущности и исторической миссии государства. Научная новизна исследования заключается в комплексном анализе освещения проблемы государственности в русской религиозной философии. В результате обосновано, что основным вопросом, вокруг которого строилось решение данной проблемы в русской философии указанного периода был вопрос 0 моральном смысле государства.

Ключевые слова: Русская религиозная философия, государственность, всеединств0, моральные основы государства, этатизм, толстовство, эсхатология.

19 - начала 20 века. Достижение данной цели потребовало решения следующих задач: во-первых, выявить основные подходы к проблеме духовных основ государственности в русской религиозной философии исследуемого периода; во-вторых, проанализировать особенности интерпретации нравственного смысла государственной власти в рамках выявленных подходов; в третьих, установить связь между представлениями русских религиозных философов о духовных основах государственности и их социально-политическими программами.

\section{Аитературный обзор}

Теоретической базой исследования послужили труды крупнейших русских религиозных философов исследуемого периода: В.С. Соловьёва, Н.К. Леонтьева, Л.Н. Толстого, Н.А. Бердяева, Л.А. Тихомирова, И.А. Ильина, а также ряд трудов по истории русской религиозной философии.

\section{Материалы и методы}

Для решения поставленных задач применялись такие методы исследования, как метод контент-анализа, 
методы анализа и синтеза, единства исторического и логического.

\section{Результаты и обсужкение}

Религиозная философия по многим признакам отличается от тех философских школ, которые определяют облик мировой мысли в начале двадцать первого века. В отличие от постмодернизма или постпозитивизма, целенаправленно сосредотачивающих своё внимание на отдельно взятой проблеме (будь то проблема существования человека в мире дискурсов или проблема демаркации науки), религиозная философия не может обойтись без создания всеобъемлющих философских систем, в которых нашли бы отображение и осмысление все ключевые проблемы всемирного, мирового и человеческого бытия. Это обусловлено самой её природой, точней - спецификой религии, как формы человеческого сознания. Составляя основу религиозно-философской мысли, религия стремиться проникнуть во все сферы жизни человека, освятив их в соответствии со своими принципами и детерминировав отношение к ним субъекта. Соответственно, последовательная религиозная философия не может позволить себе строго ограничится проблемами связи между человеком и предметом его веры, даже если такое ограничение изначально входило в задачи философа.

Среди объектов, попадающих в поле религиозной философии, одним из наиболее важных является государство. Идея государства, его отношения с личностью, нравственные основания, законодательство и регулирование жизни человека, политика и экономические связи, война и мир - всё это может иметь своеобразную интерпретацию в контексте религиозного мировоззрения, и, следовательно - может стать предметом религиозно-философского осмысления. Авраамические религии проявляют особый интерес к этим вопросам в силу присущего им отношения к человеческому существованию в материальном мире, как результату грехопадения. Государство, по их представлениям, принимает активное участие в движении человека к Богу, в преодолении человеком собственной греховности, но это участие может быть как благодетельным, так и пагубным. В государственной жизни, как отметил ещё Платон, добро и зло достигают наивысшего напряжения, и вовлекают одновременно большие группы людей. Особое значение имеет и то обстоятельство, что иудаизм, христианство и ислам в разной мере и с разными целями, но всё же санкционируют государственную организацию общественной жизни, и эта санкция неизбежно вводит её в круг интересов верующего мыслителя.

Русская религиозная философия в этом отношении не составляет исключения. Более того, в её своеобразной проблематике вопрос о государстве стал одним из центральных. С момента зарождения отечественной религиозно-философской мысли её лейтмотивом становится проблема исторической судьбы России - явление уникальное в истории мировой философии. Между тем, в силу многих исторических условий, в возникновении и развитии российской национально-политической идентичности государство играло чрезвычайно важную роль. Таким образом, интерес к государственной жизни человека сразу стал неотъемлемой чертой русской мысли. За почти два столетия её истории было выработано огромное количество различных подходов к проблеме от полного отрицания государства и его нравственного значения в произведениях Льва Толстого, и до консервативного гиперэтатизма Константина Леонтьева и Льва Тихомирова.

Несмотря на всю важность темы государства для отечественной философской традиции, до сих пор вопрос о рефлексии в ней его нравственных оснований не становился темой отдельного исследования. Как правило, он рассматривался в контексте других актуальных философских проблем, чаще всего - в контексте проблемы соотношения материального, грешного мира и Царства Божия. В трудах о. В. Зеньковского и Н.О. Лосского, посвящённых истории русской религиозной философии, проблема духовно-нравственных основ государственности рассматривается как одна из составных частей огромного комплекса проблем отечественной мысли. Наконец, тема государства часто поднимается в связи с обсуждением проблемы исторической судьбы России. Такой подход, позволяя определить место рассматриваемой проблемы в философском мировоззрении русских мыслителей, в то же время препятствовал полному пониманию всей глубины и многообразия её раскрытия в российской философии.

Формирование философской концепции государства в русской религиозной философии началось ещё в процессе дискуссии между западниками и славянофилами. Именно тогда сформировались два основных подхода к проблеме, получивших поздней развитие в отечественной мысли. Первый из них был представлен трудами П.Я. Чаадаева и характеризовался неприятием исторически сложившихся форм российской государственности. Основная причина этого неприятия - несоответствие их эталонам государственного устройства, выработанным социально-политической практикой Запада. Фактически этот подход задаёт тон последующим векам русского политического диссидентства, лейтмотивом которого стало сопоставление российских и западных (английских в 19 веке, американских - в двадцатом) политических практик и форм государственного устройства, сопоставлением, при котором российское проигрывает. Основной характеристикой российской государственности, согласно этому подходу, является рабское подчинение безликих масс самодовлеющему государству, усвоенное, 
по мнению Чаадаева, из Византии вместе с Православием. Собственно, в философскую концепцию государства российские западники не привносят ничего нового, придерживаясь выработанных в западноевропейской мысли подходов. Нравственный смысл государства они видят исключительно в воспитании народа в духе либеральных ценностей и в поддержке и распространении гражданских свобод. Государство ценно, прежде всего, тем, что оно вырабатывает в нации дух гражданства, который даёт человеку возможность свободно и самостоятельно развивать свои лучшие духовные качества.

Развитие данного подхода привело к формированию в русской философской традиции особого, самобытного направления, представленного именами Л.Н. Толстого и Н.А. Бердяева. Для этого направления типично неприятие государства как носителя определённой нравственной идеи, или, по меньшей мере, критическое к нему отношение. Государство здесь фигурирует как средоточие идеи подчинения, несвободы, рабства. Его начала представляются как противоположность началам религии, в основе которой, по мысли авторов данного подхода, лежит свободный выбор между Добром и Злом в пользу Добра. Государство, таким образом, представляет собой изначально злую силу, противостоять которой человек может и должен по мере своих сил. Мера нравственного совершенства человека - в его независимости от государства и навязанных государством идеалов. При соприкосновении идеалов христианства с действительностью государственной жизни эти идеалы размываются и искажаются. Государство - Царство Кесаря, противостоящее Царству Духа, область объективации человека. По мнению Бердяева, «...весь «христианский» мир не принял реально христианства, все еще остался языческим. Христианская история была сделкой с язычеством, компромиссом с этим миром, и из компромисса этого родилось «христианское государство» [1] и весь «христианский быт». Именно язычество, как псевдорелигия, пронизывает собой всю систему государства, все его устои. Современное государство - компромисс между бескомпромиссными врагами, между христианством и язычеством. На Западе он принимает формы папского диктата, на Востоке - форму цезарепапизма. Если западная модель государства была в некоторой степени исправлена гуманизмом и Реформацией, последовательное развитие восточной модели превратило Россию в «..оформилась в огромное, необъятное мужицкое царство, закрепощенное, безграмотное, но обладающее своей народной культурой, основанной на вере, с господствующим дворянским классом, ленивым и малокультурным, нередко утерявшим религиозную веру и национальный образ, с царем наверху, в отношении к которому сохранилась религиозная вера, с сильной бюрократией и очень тонким и хрупким культурным слоем» [1].
Противоположный подход родился в ходе дискуссии с западниками и истоки его кроются в мировоззрении славянофилов. Уже ранние представители славянофильства усматривали в государстве некое нравственное начало, тесно связанное с религией. В философии Хомякова истоки современной государственности - соединение трёх начал, Греции, Рима и Севера, причём западному типу государственности, возникшему из насильственного соединения Рима и Севера, он противопоставляет органическую государственность Руси, в которой Греция и Север соединились добровольно. Цель царства - обеспечить нравственное возрастание человека, но для этого оно должно быть основано на началах религиозных. Славянофилы воскрешают идею симфонии священства и царства, идею, пришедшую из Византии, и никогда полностью не реализованную в самой Византии. Строительство государства - акт нравственный, но только до тех пор пока идея государства не становится самодовлеющей. Царство, лишённое нравственных основ - колосс на глиняных ногах [7].

Идеи славянофилов получили дальнейшее развитие в философии В.С. Соловьёва. Соловьёв выводит идею государства из самой природы человека. По его мнению, «Жизнь человека уже сама по себе и сверху, и снизу есть невольное участие в прогрессивном существовании человечества и целого мира; достоинство этой жизни и смысл всего мироздания требуют только, чтобы это невольное участие каждого во всем становилось вольным, все более и более сознательным и свободным, т.е. действительно-личным, - чтобы каждый все более и более понимал и исполнял общее дело, как свое собственное» [4; с. 288]. Это общее дело и составляет основу общественного союза, одной из форм которого является государство. Залог устойчивости государства - нравственная свобода человека, поскольку «...самостоятельность лица есть основание крепости общественного союза». Первопричина существования государства - стремление людей к общению; государство вторично по отношению к семье, но «...национально-государственная организация - отечество - не упраздняет первичной общественной клеточки, а только изменяет ее значение» [4; с. 292]. Государство способно обеспечить свободу личности, которую не даст родоплеменной строй, оно создаёт условия для расширения и совершенствования связей между людьми, формирует среду, в которой только и возможно общественное развитие «Беззаветно отдаться какой-нибудь ограниченной и неподвижной форме общежития человек не только не обязан, но и не имеет права, ибо он мог бы это сделать лишь в ущерб своему человеческому достоинству». Следовательно, «... предприимчивый член рода нравственно прав, восставая против родового консерватизма и содействуя образованию государства, в силу которого прежние самостоятельные общественные группы превращаются в элементарные клеточки нового обширного целого» [4; с. 292]. Вместе с тем нравственная сила государства ограничена; госу- 
дарство - не абсолютная форма человеческого общежития. Нравственные начала государства важней и ценней самого государства: «Всякое общество человеческое, и в особенности общество, признающее себя христианским, может упрочить свое существование и возвысить свое достоинство, только становясь сообразным нравственной норме. Значит, дело не во внешнем охранении тех или других учреждений, которые могут быть хорошими или дурными, а только в искреннем и последовательном старании улучшать внутренно все учреждения и отношения общественные, могущие стать хорошими, все более и более подчиняя их единому и безусловному нравственному идеалу свободного единения всех в совершенном добре» [4; с. 379]. Соответственно, подлинно нравственное государство может быть основано лишь на христианских началах, поскольку лишь христианство сумело сформулировать и сохранить великую нравственную задачу братства между людьми.

Наивысшего развития концепция нравственной сущности государства достигла в мировоззрении К.Н. Леонтьева и Л.А. Тихомирова. В «Византизме и Славянстве» Леонтьев прямо указывая на византийские корни русской государственности, в то же время заявляет, что эта государственность не могла бы состояться без нравственного начала, привнесённого христианством [2; с. 305-306]. Византийский цезаризм доказал свою жизнеспособность на новой почве, но вместе с тем, он внёс в зарождающуюся государственную жизнь Руси также и начала бюрократии и деспотизма, дальнейшее развитие которых привело к духовному кризису русского мира. Этот кризис ещё более усугубился принятием при Петре и его преемниках внешних форм европейской культуры, что привело к отрыву наиболее образованной части общества от народных масс, и, что наиболее трагично - к разрыву с христианской традицией, изначально лежавшей в основе русской государственной идеи. В итоге, как отмечает Леонтьев в статье, посвящённой Пушкин- ской речи Ф.М. Достоевского, Россия утрачивает «...на наших глазах даже прославленный иностранцами государственный инстинкт свой» [3].

Подобно Леонтьеву, Л.А. Тихомиров связывает истоки государства с религиозно-нравственными причинами. По его мнению, государство возникает как развитие идеи власти, идеи, заложенной в самой природе человека [5; с. 42]. Рассматривая психологические и биологические основы власти, он отдаёт тем не менее приоритет нравственному чувству, которое свойственно каждому человеку и которое определяет возникновение идеи порядка и связь этой идеи с религиозным чувством. Цель власти - быть орудием «правды», служить торжеству нравственного начала в мире. Тихомиров разрабатывает идею государства, как высшей формы организации общества. Только государство может охранить свободу от всеразрушающей анархии, только государство гарантирует безопасность человека в мире, подверженном греху. Однако Тихомиров не сводит свободу лишь к понятию свободы политической. Свобода для него - прежде всего, свобода нравственного роста и самосовершенствования [6; с. 379].

\section{Зак^ючение}

Таким образом, в отечественной религиозно-философской мысли 19 - начала 20 века господствовали и противостояли друг другу две концепции нравственных начал государственности. Согласно одной из них, государство есть сфера несвободы человека, результат его неспособности противостоять «соблазну царства»; духовная свобода человека достигается лишь путём выхода его духа и совести из-под гнёта государства. Противоположная точка зрения основана на представлении о государстве, как о выражении определённой религиозно-нравственной идеи, тесно связанной с основами христианского мировоззрения.

\section{ЛИТЕРАТУРА}

1. Бердяев Н.А. Философия свободы. [Электронный ресурс]: Библиотека русской религиозно-философской и художественной литературы «ВБхи». URL: http://www.vehi.net/berdyaev/filos_svob/index.html (дата обращения 20.10.2020)

2. Леонтьев К.Н. Византизм и Славянство. /К.Н. Леонтьев. Полное собрание сочинений в 7 томах. Т. 7; кн. - СПб.: Изд-во «Владимир Даль», 1999. С. $300-444$.

3. Леонтьев К.Н. 0 всемирной любви. Речь Ф.М. Достоевского на пушкинском празднике. [Электронный ресурс]. Библиотека русской религиозно-философской и художественной литературы «Bちхи». URL: http://www.vehi.net/leontev/dost.html (дата обращения: 15.11.2020).

4. Соловьёв В.С. Оправдание добра. Нравственная философия // Соловьёв В.С. Сочинения: в 2-х т. Изд. 2-е. М.: Мысль, 1990. Т. 1. 892+2 с.

5. Тихомиров Л.А. Монархическая государственность / Т46 Л.А. Тихомиров; [сост., автор вступ. ст., коммент. А.В. Репников]. 一 М. : Российская политическая энциклопедия (РОССПЭН), 2010. —752 c. — (Библиотека отечественной общественной мысли с древнейших времен до начала XX века).

6. Тихомиров Л.А. Религиозно-философские основы истории. М.: Айрис-пресс, Лагуна-Арт, 2004. - 688 с.

7. Х Хомяков А.С. Несколько слов православного христианина о западных вероисповеданиях. По поводу брошюры г. Лоранси. [Электронный ресурс]: Библиотека русской религиозно-философской и художественной литературы «ВБхи». URL: http://www.vehi.net/khomyakov/katolichestvo.html (дата обращения 20.10.2020)

(ㄷ Громов Егор Валерьевич (gromove@mail.ru). 